considerable impact on both policy dialogue and policy making in health, education, social welfare and criminal justice (e.g. Layard, 2006). National governments, economists and public health advisors, as well as local services, depend on such information. It would be a shame for other countries if the UK were to remain the only country with the required precise and customised information available. We feel the British approaches and methods have been able to provide a cost-effective balance of information on dimensions and categories, determinants and consequences, health and social service use and other behaviours.

\section{References}

Bebbington, P., Dunn, A., Jenkins, R., et al (1998) The influence of age and sex on the prevalence of depressive conditions: report for the National Survey of Psychiatric Morbidity. Psychological Medicine, 28, 9-19.

Bebbington, P. E., Meltzer, H., Brugha, T., et al (2000) Unequal access and unmet need: neurotic disorders and the use of primary care services. Psychological Medicine, 30, 1359-1367.

Bebbington, P. E., Bhugra, D., Brugha, T., et al (2004) Psychosis, victimisation and childhood disadvantage: evidence from the Second British National Survey of Psychiatric Epidemiology. British Journal of Psychiatry, 185, 220-226.

Brugha, T. S., Morgan, Z., Bebbington, P., et al (2003) Social support networks and type of neurotic symptom among adults in British households. Psychological Medicine, 33, 307-318.

Brugha, T. S., Bebbington, P. E., Singleton, N., et al (2004) Trends in service use and treatment for mental disorders in adults throughout Great Britain. British Journal of Psychiatry, 185, 378-384.

Brugha, T., Singleton, N., Meltzer, H., et al (2005) Psychosis in the community and in prisons: a report from the British National Survey of Psychiatric Morbidity. American Journal of Psychiatry, 162, 774-780.
Coid, J., Yang, M., Roberts, A., et al (2006) Violence and psychiatric morbidity in a national household population - a report from the British Household Survey. American Journal of Epidemiology, 164, 1199-1208.

Farrell, M., Boys, A., Singleton, N., et al (2006) Predictors of mental health service utilisation in the 12 months before imprisonment: analysis of results from a national prisons survey. Australian and New Zealand Journal of Psychiatry, 40, 548-553.

Goodman, R., Ford, T., Richards, H., et al (2000) The Development and Well-Being Assessment: description and initial validation of an integrated assessment of child and adolescent psychopathology. Journal of Child Psychology and Psychiatry, 41, 645-655.

Jenkins, R., Lewis, G., Bebbington, P., et al (1997) The National Psychiatric Morbidity Surveys of Great Britain: strategy and methods. Psychological Medicine, 27, 765-774

Jenkins, R., Brugha, D., Meltzer, H., et al (2005) Psychiatric and social aspects of suicidal behaviour in prisons. Psychological Medicine, 35, 257-269.

Johns, L. C., Cannon, M., Singleton, N., et al (2004) The prevalence and correlates of self-reported psychotic symptoms in the British population. British Journal of Psychiatry, 185, 298-305.

Layard, R. (2006). The case for psychological treatment centres. BMJ Clinical Research Edition, 332, 1030-1032.

Melzer, D., Fryers, T., Jenkins, R., et al (2003) Social position and the common mental disorders with disability: estimates from the National Psychiatric Survey of Great Britain. Social Psychiatry and Psychiatric Epidemiology, 38, 238-243.

Moran, P., Stewart, R., Brugha, T., et al (2007) Personality disorder and cardiovascular disease: results from a national household survey. Journal of Clinical Psychiatry, 68, 69-74.

Skapinakis, P., Weich, S., Lewis, G., et al (2006) Socio-economic position and common mental disorders. Longitudinal study in the general population in the UK. British Journal of Psychiatry, 189, 109-117.

Targosz, S., Bebbington, P., Brugha, T., et al (2003) Lone mothers, social exclusion and depression. Psychological Medicine, 33, 715-722.

Vostanis, P., Brugha, T., Goodman, R., et al (2006) Relationship between parental psychopathology, parenting strategies and child mental health: findings from the GB national study. Social Psychiatry and Psychiatric Epidemiology, 41, 509-514.

SPECIAL PAPER

\title{
Perambulations of a President
}

\section{Sheila Hollins}

President, Royal College of Psychiatrists, email shollins@rcpsych.ac.uk

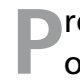

revious Presidents wrote Council reports of their overseas visits and one wonders how wide an audience their reflections actually reached. What good fortune for me, then, that I can share my reflections in the pages of International Psychiatry. The title of this paper was given to me by a disgruntled senior member of the College working in England, who felt that I was paying far too much attention to international matters, and so I thought I should explain further why I consider the international role of the College to be so important.

The College has some 13000 Members and Fellows, of whom about a fifth work overseas. Of those members working in the UK, about a quarter graduated from an overseas medical school and then came to the UK either for postgraduate studies in psychiatry or as an economic migrant, sometimes in direct response to active recruitment by UK governments. Many of those who came here after graduation have retained strong family and even professional links within their country of origin. Some $40 \%$ of members have ongoing active links with another country, whether as residents or non-residents. This does not even include doctors in staff-grade posts, where the proportion of international medical graduates is even higher. For several years now, overseas members have been able to belong to an international division and the Board of International Affairs has been working hard to determine their needs.

When I became President I made a commitment to visit all the College's divisions. To my surprise, invitations have been more forthcoming from the College's international divisions than from the UK and Ireland. The College has agreed that I should try to time my visits to coincide with meetings of the officers and members of these divisions, and that the College should host a social event for all division members and friends, to facilitate networking. For financial reasons, such meetings need to 'piggy back' on to conferences in the appropriate region of the world, but even so it is often difficult for many of our members to join in such events. It is, of course, a privilege to visit another country and to hear about 
the aspirations and challenges facing our Members and Fellows, and their patients and carers.

\section{America}

Most of us share a common language and some common experience; after all, most of our Members and Fellows understand the UK situation, having trained here. This is not always the case, however, as I found during my recent visit to the American Psychiatric Association (APA) conference in San Diego, where the College participated in a joint presidential symposium with the APA President on health inequalities for people with developmental disabilities or people with mental illness. The stark contrast between our different healthcare delivery systems and the different fundamental concepts underlying the commissioning (funding) of services certainly served to obfuscate our attempts to communicate fully. I suggested that our two countries are divided by a common language - a language which we understand differently because of our cultural differences. That said, listening to each other about clinical issues and human factors affecting people's lives brought us closer together again.

I was shocked when one young resident in child psychiatry told me that in her specialty no one 'needs' to work in the public sector, nor to accept patients covered by insurance (I think she meant through a preferred provider contract, where doctors are paid a smaller fee) because there are enough wealthy parents to employ all the child psychiatrists in the land. Quite a contrast, then, to hear an inspiring call, from an American psychiatrist working with people with intellectual disabilities, for every psychiatrist to take on 17.5 patients with an intellectual disability in order to provide a service to the number of people in this group he estimates to have a concurrent mental illness. I left the conference feeling pleased that there was some shared interest in the mental health of populations.

I also had an opportunity to visit an independent mental healthcare provider in Baltimore that first opened its doors in 1891, having been built by a Quaker gentleman of means (the Sheppard Pratt Health System; http://www. sheppardpratt.org). There I was also asked to talk about similarities and differences between our healthcare systems. It would have been so much easier to talk about mental disorders and current treatment approaches!

\section{Africa}

In Nairobi in March 2007 I was able to attend the first regional meeting of the World Psychiatric Association (WPA) in Africa. This was one of the best conferences I have attended in recent years, with a very high quality of presentations and excellent opportunities to meet colleagues.

I was interested to meet the psychiatrists from Tanzania, whose response to the lack of psychiatrists (around 12 for a population of 34 million) has been to train primary care doctors to diagnose and treat mental disorders. I had seen this in action in a small town in Tanzania the week before the conference, and been impressed by the attitude and interest in mental health of the single-handed primary care physician working in the community hospital.
At the division's business meeting with other College officers, we were convinced that benefits for our members working in Africa should be tailored to their actual needs and ability to pay, and discussions are ongoing about this.

\section{Pakistan}

The South Asian Division organised a demanding schedule for me in Pakistan in February to coincide with the First International Conference of the WPA Section on Psychiatry in Developing Countries. Besides the now customary party for members and guests (and our chief guest on this occasion was the Foreign Minister of Pakistan), and a College symposium at which members of five international divisions spoke about psychiatry in developing countries, my hosts also wanted me to help raise awareness of mental health issues across northern Pakistan. Their concerns were particularly in response to the longer-term mental health needs of survivors of the earthquake in October 2005, and so a visit to Kashmir was essential. It was a 1500-mile bumpy ride in a small bus over 3 days.

The trip to Muzzafarabad was on a rainy, misty and chilly day that began at dawn and ended at midnight. We were welcomed by the two local psychiatrists (the only psychiatrists working in the area), who described some of the mental health problems experienced by those affected by the earthquake, and their own need for ongoing support and training. Each time we stopped, local dignitaries who wanted to talk to us about the earthquake also greeted us. This culminated in a meeting with the Prime Minister of Kashmir, when we spoke to parliamentarians and civil servants and heard their perspective on how mental health problems were delaying recovery and reconstruction for many of those who had survived. This meeting was televised and an extract appeared on the national news that day - a good outcome as our aim was to raise the profile of mental disorders and the role of psychiatrists in a country where there are only 350 psychiatrists for a population of over 164 million - over twice that of the UK.

To put this in perspective, approximately 350 Pakistani psychiatrists are working in the UK, many of whom return regularly to Pakistan to share their skills. I visited one such doctor who joined the College Volunteer Scheme on unpaid leave from the National Health Service (NHS), in response to a request for a child psychiatrist to work in and near Rawalpindi. Her clientele include children affected by the earthquake, but an important role is to provide some training in child psychiatry. This is likely to be an ongoing need and the College International Manager is seeking a successor for this post as well as for other similar requests.

\section{International recruitment}

The Board of International Affairs has for some time been worried about the effect of international migration on the sustainability of psychiatry and the development of mental health services in many parts of the world. The College has not supported past government policy in the UK to actively recruit doctors from developing countries to fill specialist vacancies in the NHS. However, it has been keen to support the training needs of colleagues coming from abroad to gain 
experience and qualifications. At the quadrennial meeting of the WPA in Cairo in 2004, I raised this issue for discussion and asked the WPA executive to set up a task force to examine the problem and to see what action could be recommended to introduce some reciprocity into this situation, recognising that individuals are free to make their own decisions about where they live and work, subject to different countries' immigration rules. The task force held its first meeting in April 2007 under the chairmanship of Professor Oye Gureji.

\section{Conclusion}

As I left our annual meeting this year I was thanked by an African psychiatrist for making it possible for him and some of his colleagues to join us in Edinburgh. He said he wanted the College to know just how important it is that we do offer this kind of support to colleagues from Africa. He said, 'You can't know just how important your interest and support is to us'. This is a good enough reason for me to continue my listening perambulations!

\section{European Division}

The European Division of the College contributed to the $1 \mathrm{st}$ Psychiatric Congress of Eastern Europe, organised by the Psychiatric Association for Eastern Europe and the Balkans (www.paeeb.com), held in Thessaloniki, Greece, 21-23 September 2007. We arranged two courses, one on organisation of psychiatric services, chaired by Anne Lindhardt, and one on forensic psychiatry, chaired by Athanasios Douzenis and Christos Tsopelas.

During the General Assembly representatives from 13 countries passed the Declaration of Thessaloniki, which urges the international scientific community, the World Psychiatric Association (WPA), the World Health Organization, the political leadership and all other relevant organisations to contribute to the reconstruction and advancement mental health services in Eastern Europe and the Balkans. The full text of the declaration is available on the PAEEB website.

Professor George Christodoulou

\section{Western Pacific Division}

The Western Pacific Division continues to promote the aims of the College in its vast region, with over 700 Members and Fellows but also one-third of humankind. We believe that organising training in services and research is by far the greatest priority, where this is practicable. In this context, the Division is eager to support and contribute to activities of the College in the Western Pacific, including the proposed Royal College Membership Examinations in Hong Kong. There is interest in identifying similarities and differences between the RCPsych and the Royal Australian and New Zealand College of Psychiatrists (RANZCP) in relation to training, examination and accreditation, and whether these are likely to change.

The Division is most grateful to Professor Bruce Singh for his assistance in organising a symposium held at the WPA conference in Melbourne in November 2007, jointly with the RANZCP and the Australasian Society for Psychiatric Research.

Professor Scott Henderson

\section{College international travel}

The WPA Regional Conference and the Chinese Psychiatric Society Annual Congress were held in Shanghai, China, 20-23 September 2007. The College delegation included
Professor Sheila Hollins, President, Professor Sue Bailey, Registrar, Dr Tony Zigmond, Vice-President, and Joanna Carroll, International Manager. In addition to presenting a session on mental health legislation around the world, our main objective was to initiate contact with psychiatrists in mainland China and to meet representatives of relevant organisations with a view to discussing collaboration. We had a very fruitful meeting with the British Council. Our public education materials and the volunteer programme were of particular interest to them and we will be exploring this further with the Chinese Health Bureau in Shanghai. Our impromptu visit to the Shanghai Mental Health Centre gave us a valuable overview of Shanghai mental health services. The formal business at the Congress included a poster presentation about the College's international work and a College symposium on developing and implementing mental health legislation around the world. The full post-conference report is available on the College website (http://www.rcpsych.ac.uk/ college/internationalaffairsunit/westernpacificdivision.aspx).

\section{UEMS Section and Board of Psychiatry}

At the Section and Board of Psychiatry autumn meeting held in Geneva last October, Dr Kari Pylkkänen, of the Finnish Medical Association, was elected President of the Section of Psychiatry; Dr Brigitte Mauthner, of the Austrian Medical Chamber, is the new Vice-President of the Section, and Dr Brendan Cassidy, of the Irish Medical Organisation, was elected Treasurer of both the Section and the Board. Dr Joseph Saliba, from Malta, continues in his final term of office as Honorary Secretary, and Professor Slavko Ziherl was re-elected Vice-President of the European Board of Psychiatry.

\section{Bobby Somasunderam memorial}

The South Asian Federation (SAF) has joined forces with the WPA Section on Psychiatry in Developing Countries to launch a fundraising project for the Bobby Somasunderam Memorial at Government Mental Hospital in Angoda, Colombo, Sri Lanka. A ward at Angoda Hospital for patients with intellectual disability will be named after him; the project will also offer training for the staff. For further details please contact Dr Afzal Javed, email afzal@afzaljaved.co.uk.

Dr Afzal Javed 